\title{
QUEEN'S
UNIVERSITY
BELFAST
}

\section{Understanding the Kurdish conflict through the perspectives of the Kurdish-Turkish diaspora in Germany}

Unal, H., Blaylock, D., \& Uluğ, Ö. M. (2020). Understanding the Kurdish conflict through the perspectives of the Kurdish-Turkish diaspora in Germany. Peace and Conflict: Journal of Peace Psychology .

https://doi.org/10.1037/pac0000485

Published in:

Peace and Conflict: Journal of Peace Psychology

Document Version:

Peer reviewed version

Queen's University Belfast - Research Portal:

Link to publication record in Queen's University Belfast Research Portal

\section{Publisher rights}

Copyright 2020 American Psychological Association.

This manuscript is distributed under a Creative Commons Attribution-NonCommercial-NoDerivs License

(https://creativecommons.org/licenses/by-nc-nd/4.0/), which permits distribution and reproduction for non-commercial purposes, provided the author and source are cited.

\section{General rights}

Copyright for the publications made accessible via the Queen's University Belfast Research Portal is retained by the author(s) and / or other copyright owners and it is a condition of accessing these publications that users recognise and abide by the legal requirements associated with these rights.

Take down policy

The Research Portal is Queen's institutional repository that provides access to Queen's research output. Every effort has been made to ensure that content in the Research Portal does not infringe any person's rights, or applicable UK laws. If you discover content in the Research Portal that you believe breaches copyright or violates any law, please contact openaccess@qub.ac.uk. 


\section{KURDISH-TURKISH DIASPORA IN GERMANY}

\section{Understanding the Kurdish Conflict through the Perspectives of the Kurdish- Turkish Diaspora in Germany}

The perspectives of lay people within conflict settings are important because the ways in which they perceive and understand ongoing conflict can shape its course. While limited, existing research suggests that diaspora communities can also play a pivotal role in influencing conflict from outside their homeland; however, systematic examination of the different ways that members of diaspora communities frame conflict occurring within their homelands has not received attention. Using Entman's (1993) systematic frames analysis, research by Uluğ and Cohrs's (2016) examined conflict frames used by lay people from different ethnic groups in Turkey. The current research replicates and extends this work by examining conflict frames used by members of the Kurdish-Turkish diaspora in Germany following the same frame analysis: a) problem definitions, b) sources of the problem, c) moral evaluations, d) solutions to the problem, and e) barriers to the solution of the problem. Q methodology, a mixed-methods approach, was used to discover socially shared viewpoints regarding the Kurdish conflict with 43 people from the Kurdish and Turkish diaspora in Germany. Results highlighted four different conflict frames, labeled as a) a freedom for Öcalan frame; b) a nation-state ideology and democracy frame; c) an independence and identity for Kurds frame; and d) a terrorism, economy, and foreign power frame. These diverse viewpoints are evidence of the importance of emphasizing the role of diaspora groups' perspectives in conflict resolution and peace process. The article concludes with a discussion of similarities and differences across lay people in Turkey and diasporic communities in Germany.

Keywords: diaspora, Germany, Kurdish conflict, frame analysis, Q methodology 


\section{KURDISH-TURKISH DIASPORA IN GERMANY}

\section{Understanding the Kurdish Conflict through the Perspectives of the Kurdish-Turkish Diaspora in Germany}

People are generally motivated to identify with and feel positive about their groups (Tajfel, 1974; Tajfel \& Turner, 1986). Identity groups help to express and satisfy groups' own needs. However, when a group's basic needs are denied, intergroup conflicts can easily break out (Fisher, 2006).

Group dynamics based on shared identities play a key role in the outbreak and development of a conflict (Uluğ \& Cohrs, 2019) and there are myriad examples showing how negative intergroup relationships related to identity dynamics can result in conflict and violence within a society, including the conflicts in Bosnia, Palestine, and Sri Lanka (Staub, 2018). Each case of conflict has its unique characteristics, and conflicts can be classified into several different categories. One of the more malicious forms that conflict can take is the long-lasting, intractable conflict, which is often characterized by high levels of violence. When violence is a part of a conflict, it changes the context of the conflict and inevitably creates refugees (Bar-Tal, 2007). This migration brings complications to the conflict in terms of understanding intergroup relationships, peace processes, and violence as it crosses borders.

As refugee flows increase and affect international politics and conflict, it is vital to include refugees' perspectives into the conflict context and understand how they perceive and ultimately engage with the conflict. Those uprooted groups of people can be called diasporas. While the term "diaspora" does not have a settled definition in the literature, the most common definition used by scholars is that of "a people with a common origin who reside, more or less on a permanent basis, outside the borders of their ethnic or religious homeland" (Shain \& Barth, 2003, p. 452). Members of the diaspora who flee from their country may remain involved with 


\section{KURDISH-TURKISH DIASPORA IN GERMANY}

ongoing conflict by establishing third party allies and organizing demonstrations in their host country (Baser, 2017a); as such they can play a crucial role in the politics and political decisionmaking processes of homelands and hostlands in supporting peace processes or violence (Baser \& Swain, 2008). The diaspora's involvement in conflict represents a new era in international politics and requires urgent attention (Smith, 2007). As conflict changes people's beliefs, goals, norms, and values (Jeong, 2010), these changes will influence people in the diaspora, which in turn, influences the course of the ongoing conflict. Unfortunately, in social and political psychology, researchers have not systematically examined the ways in which members of the diaspora perceive and understand the conflict in the homelands (see, e.g., Wohl, King, \& Taylor, 2014). While existing literature is silent on diasporas' involvement in conflict, this study aims to shed light on these understudied aspects of the conflict from diasporas' perspectives.

Building upon the work of Uluğ and Cohrs (2016), which was conducted in the homeland (i.e., Turkey), the current study aims to replicate their study by extending it to diaspora members. To be more specific, we aim to understand how diaspora members in Germany perceive and frame the Kurdish conflict in the homeland country (i.e., Turkey) to contribute to the literature by showing the role of diaspora perspectives in conflict. First, we provide the historical background of the Kurdish conflict, the Kurdish-Turkish diaspora in Germany, and the role of diasporas in conflict. We then present an empirical study of 43 diaspora members using a mixedmethod, Q methodology, approach. Next, we compare the findings of the current study with those of Uluğ and Cohrs (2016) and discuss the implications of this work for understanding the role of the diaspora in conflict resolution. Finally, we conclude with a discussion of the limitations of our current knowledge and provide suggestions for future research.

\section{Historical Background of the Kurdish Conflict}




\section{KURDISH-TURKISH DIASPORA IN GERMANY}

The Kurdish conflict has a long history that extends back into the days of the Ottoman Empire. The reason behind the Kurdish conflict has changed with changing political situations. After the dismantling of the Ottoman Empire, several nations became independent, and the Kurdish conflict gradually began. Each of the regional states has had its own Kurdish policy.

The fundamental reasons for the conflict can be understood as political centralization, the nationalization of culture, identity, territory, and sovereignty (Ozsoy, 2013). Accordingly, the nationalization of Turkish culture and identity in Turkey prevented Kurds from expressing their identity and culture, resulting in open rebellion by various Kurdish insurgent groups over the years. The armed struggle continues today with the PKK (Partiya Karkerên Kurdistan/Kurdistan Workers' Party), which was founded in 1978 under the leadership of Abdullah Öcalan. The PKK has become one of the main actors in the conflict. Therefore, the Kurdish conflict may be defined as a conflict between the Turkish state and the PKK (see Çelik \& Blum, 2007).

In 2005, the then Prime Minister Recep Tayyip Erdoğan officially recognized the Kurdish problem. Following this official recognition, a secret negotiation began in Oslo in 2009 between the government and the PKK. Negotiations continued until 2011 when news of the negotiations was anonymously leaked to the public resulting in mutual distrust between the parties; it also did not help the process that the level of violence between the groups subsequently increased. However, in December 2012, Erdoğan announced negotiations between the Turkish government and Öcalan to resolve the conflict, calling it a "peace process." In 2013, the PKK declared a cease-fire and withdrew its militants from Turkey to the PKK's headquarter in Mount Qandil to expedite the peace process (Ozkahraman, 2017).

This peace process, however, collapsed in 2015 with both parties blaming the other. The Turkish government claimed that it ended because the PKK killed two police officers in their 


\section{KURDISH-TURKISH DIASPORA IN GERMANY}

homes on 22 July 2015, an accusation which the PKK denied. For their part, the PKK blamed the AKP (Adalet ve Kalkınma Partisi/Justice and Development Party) government for ignoring the attack in Suruç where the Islamic State of Iraq and the Levant's (ISIL) killed 32 young people, who were planning to reconstruct the city of Kobanî, on 20 July 2015. Additionally, the ongoing war in Syria may have contributed to the collapse. The YPG (Yekîneyên Parastina Gel/People's Protection Units), an affiliate of the PKK, declared its autonomy in the Turkish/Syrian border town of Kobanî. The YPG's declaration of autonomy is important for the non-state Kurds who want to establish an independent state. The Turkish government strictly opposed this idea and responded with diplomatic and political attacks against the YPG. Moreover, following the ISIL siege of Kobanî in October 2014, the Kurdish protesters in Turkey started to support the town of Kobanî and protest against the Turkish foreign policy towards Syria. The protests lasted for 10 days resulting in more than 30 civilians deaths (Yuksel-Pecen, 2018). The Turkish state's foreign policy towards Syria and brutal response to the protestors also played a role in derailing the peace process.

These protests also received support from Kurds living in Europe, especially in Germany, which has the highest number of Kurdish immigrants in Europe. During this time, the Kurdish diaspora played a crucial role in raising awareness in Europe about the Kurdish conflict in Turkey through protests and lobbying efforts (Baser, 2017a). After the peace process ended in Turkey, Kurds were not alone in the German streets as pro-Turkish government supporters also gathered to protest against Kurds and their cause (Aydın, 2016).

\section{The Kurdish and Turkish Diaspora in Germany}

Germany is one of the countries which has received both immigrants and political asylum seekers from Turkey. After the Second World War, Germany had a strong demand for labor and 


\section{KURDISH-TURKISH DIASPORA IN GERMANY}

established the Guest Worker System in the late 1950s and early 1960s. Germany signed this treaty with Turkey in 1961 and 1964 (Chapin, 1996). Kurdish immigration to Germany started in the 1960s with laborers; however, due to mounting oppression against Kurds in Turkey, the number of political asylum seekers increased rapidly in the mid-1970s (Baser, 2017b). The 1980's military coup had a devastating effect on the PKK militants. While some militants were imprisoned or killed, a number fled to Europe (Casier, 2011). The coup also affected the lives of many other Kurdish civilians, motivating many to move to European countries as many were facing charges for terrorism. Current estimates suggest that there are more than a million Kurds who have left Turkey, with the majority now living in European countries either as refugees or immigrants, and more than 600,000 Kurds live in Germany (Ammann, 2005).

The Turkish diaspora has a similar story as the Kurdish diaspora. Nearly 800,000 Turks went to Germany, the Netherlands, and France between 1961 and 1974 as laborers, and Germany hosts the highest number of Turkish immigrants (Memcutek \& Baser, 2018). Turkish immigration started mostly as laborers, and the Turkish government also encouraged its citizens to migrate to Europe for several reasons, such as to relieve pressure on its labor market and prevent socio-economic tension in Turkey (Aydin, 2016). Family unification was another reason for immigration. As of today, approximately 3.5 million Turkish citizens live in Europe (İçduygu, 2012), and nearly 2.4 million live in Germany (Østergaard-Nielsen, 2003).

\section{The Role of Diasporas in Conflict}

Diasporas may play different roles in conflict. By their very nature, diasporas are heterogeneous social groups that settle and establish themselves in a host country (Smith, 2007). Groups within the same diaspora can have different attitudes and perspectives regarding the conflict, as well as differing levels of political activism (Baser, 2017b; Smith, 2007). 


\section{KURDISH-TURKISH DIASPORA IN GERMANY}

Participation in political activism can play a constructive and destructive role in conflict, and its role depends on many factors such as a diaspora groups' power and their political standing in the host country (Bercovitch, 2007).

Research suggests that diasporas are able to influence political, social, and economic developments in both their home and host countries (Baser, 2017a). For instance, during the Northern Irish Troubles, the Irish Republican Army (IRA) received financial support from members of the Irish American diaspora and Irish Americans played a significant role in lobbying the US government on behalf of the conflicting party (Adamson, 2002). Similarly, Somalians received economic remittances from members of the Somalian diaspora who have contributed toward rebuilding Somalia. The Somalian diaspora also played an active role in peacebuilding through awareness-raising efforts such as presenting conferences and workshops abroad (Pirkkalainen \& Adbile, 2009).

Conversely, diasporas also can be obstacles to conflict resolution, and peacebuilding as individuals and groups with more nationalist views can engage in more radical strategies such as funding extremist militias in their homeland country (Spear, 2006). In other words, the roles that diasporas play are not uniform but can vary considerably (Koinova, 2009). Accordingly, the ways in which members of the diaspora perceive and understand conflict is of paramount interest.

\section{The Present Research}

The present research aims to explore how the Kurdish and Turkish diasporas in Germany perceive and frame the Kurdish conflict in Turkey. While diaspora communities might play different roles such as peace-makers or peace-wreaking in homeland and hostland, their understanding of conflict also highlights many other aspects that might play a role in conflict and 


\section{KURDISH-TURKISH DIASPORA IN GERMANY}

helping us to reframe conflict. To explore conflict frames (i.e., frames that people use to make sense of conflict and conflict resolution) and replicate the previous study, the systematic frame analysis of Entman (1993) and Uluğ and Cohrs's (2016) five modified domains were adopted as a) problem definition, b) source of the problem, c) moral evaluation, d) solution to the problem and e) barrier to the solution of the problem. Similarly, the current study aims to contribute to the literature by focusing on the perspective of Kurds and Turks to explore how they frame the Kurdish conflict in Germany by using a systematic frame analysis as well as Uluğ and Cohrs's (2016) five modified domains.

\section{Method}

Q methodology, a mixed-methods approach, was particularly well suited for the present research as it enables us to systematically analyze and interpret participants' opinions (Watts \& Stenner, 2012). In Q methodology, both qualitative and quantitative techniques are combined (Brown, 2004), allowing human subjectivity to be measured through the strengths of both techniques (Akhtar-Danesh, Baumann, \& Cordingley, 2008). The qualitative strength lies in the capacity to examine how people think and why they do so regarding that particular issue, whereas the quantitative strength lies in the capacity to use factor analysis to identify likeminded individuals regarding an issue (Brown, 2004). The method helps to uncover socially shared viewpoints and identify aspects of agreement and disagreement among conflicting parties (Shinebourne, 2009). It can also be used to explore which particular issues are more or less important for each group (Watts \& Stenner, 2005). In this study, the issue referred to is the Kurdish conflict, and the participants reflected on which topics in the context of the Kurdish conflict are central for them. As such, the methodology was appropriate for investigating 


\section{KURDISH-TURKISH DIASPORA IN GERMANY}

individuals' agreement/disagreement points and their holistic viewpoints in relation to the Kurdish conflict.

\section{Recruitment}

Q methodology does not require large samples; an ideal sample size is between 40-60 people to have in-depth perspectives and beneficial comments (Shinebourne, 2009). Furthermore, Q methodology does not require a representative sample because it uses purposive sampling, and it assumes that each person will have a different point of view (Cuppen, Breukers, Hisschemöller, \& Bergsma, 2010). In other words, it aims to include participants who can provide a wide range of viewpoints (see, e.g., Uluğ \& Cohrs, 2016).

To ensure as heterogeneous of a sample as possible, a snowball method was used. Arrangements through personal contacts were made for the first author to work in Germany with a number of people having access to Kurdish and Turkish members of the diaspora; this served as the initial stage of the participant recruitment. To ensure equal representation of both ethnic groups and as wide a range of viewpoints as possible, in the second stage of recruitment after each meeting, participants were asked if they knew someone who had a different perspective than theirs after which the researcher reached out to these individuals (see, e.g., Uluğ \& Cohrs, $2016 ; 2017 a)$.

\section{Participants}

The data was collected between March and April 2018, three years after the peace process failed. For the current study, individuals were recruited who were over the age 18 years and had lived in Germany for at least 10 years, a period which arguably gives an individual long enough to experience their new community. Overall, 43 people agreed to participate in the study who were between the ages of 28 and 73 years $(M=47.58 ; S D=10.77)$, of which 26 were male 


\section{KURDISH-TURKISH DIASPORA IN GERMANY}

and 17 were female. The number of years of residence in Germany for the participants ranged from 10 to 47 years $(M=27.21 ; S D=11.39)$.

In terms of ethnic background, when asked the question, "Which one describes you better?" 14 participants self-identified as Turkish, while two others chose both Turkish and German, Turkish and human; one chose Turkish and Kurdish. Twenty-one participants identified as Kurdish. Four Turkish-speaking participants defined themselves as human persons, internationals, and citizen of the world based on having the multiple choices of a) Turkish, b) Kurdish, c) Armenian, d) German, and e) other. Only one person who was a native-Kurdish speaker identified as a world citizen (see Table 1 for factor loadings and participants' characteristics).

\section{Insert Table 1}

\section{Materials}

To ascertain the different conflict views used by the participants, they were provided with 54 statements related to the Kurdish conflict. Each statement was in Turkish, numbered, and printed on a separate card. Each of the different statements was related to one of five domains: the definitions of the Kurdish problem (11 statements), causes of the Kurdish problem (7 statements), moral judgments of the Kurdish conflict (13 statements), possible solutions for the Kurdish problem (16 statements), and potential barriers to resolving the Kurdish conflict (7 statements; see also Uluğ, Odağ, Cohrs, \& Holtz, 2017). The specific 54 statements have been used in previous work exploring the Kurdish conflict (Uluğ \& Cohrs, 2016; 2017a; 2017b) and were derived from focus group discussions (see also Uluğ et al., 2017), academic articles, books, 


\section{KURDISH-TURKISH DIASPORA IN GERMANY}

newspaper articles, party programs, transcriptions of speeches by political party leaders, and survey results of NGOs, and a previous Q methodology study (Uluğ \& Cohrs, 2019), with only slight adaptations made to suit the current study. We replaced BDP (Peace and Democracy Party) with HDP (People's Democratic Party); Oslo negotiations with İmralı (an island prison in Turkey where Öcalan has been kept since 1999) negotiations; MHP (Nationalist Movement Party) with Turkish nationalists. These minor changes were necessary to reflect the current political situation in Turkey. For example, the BDP changed its name, the Oslo negotiations were replaced with the İmralı negotiations, and the MHP's political situation changed. When Uluğ and Cohrs (2016) started searching for different perspectives on the Kurdish conflict, they first ended up with 106 statements. After that, they consulted seven scholars who are knowledgeable about the Kurdish conflict to determine whether 1) the statements were comprehensive and clear; 2) there were any repetitions, overlaps, or any missing content; and 3) the perspectives of different groups were represented. After scholars' evaluation, Uluğ and Cohrs (2016) reduced the number of statements to 54 .

\section{Procedure}

The first author met all the participants in person at a venue in which they felt most comfortable; this included their homes, cafés, workplaces, and, for a small number, in the political organizations where they worked (e.g., Alevi or pro-Kurdish organizations). The participants were asked to complete an informed consent form to take part in the study, after which they were given the set of cards with the 54 different statements about the Kurdish conflict to start the Q-sorting process (i.e., sorting the cards on cardboard).

Upon receiving the cards, participants were first asked to sort them into three categories such as "agree," "disagree," and "neutral." As a second step, the participants were asked to place 


\section{KURDISH-TURKISH DIASPORA IN GERMANY}

these cards into a fixed quasi-normal distribution (see Figure 1 for the fixed quasi-normal distribution), which was drawn on a cardboard. Starting with the "agree" pile, participants were told to sort the cards beginning with the card they most agreed with at +5 , continuing until all cards in the agree pile were placed. A similar procedure was used for the "disagree" pile (e.g., at -5). Finally, they placed the remaining cards into the neutral category.

During this process, the participants compared each of the cards with the others and, thereby, constructed their viewpoint in relation to one another. The participants were encouraged to make comments about the statements during the sorting process. There were no interview sessions or records of participants. After sorting all the cards, they were asked if they would like to change any of the cards about which they were unsure. After being satisfied with their placement of the cards, they were asked to comment on the cards they placed in the most agreed and most disagreed piles and why they sorted these statements there.

Notes on their additional comments were written down on a separate sheet of paper during data collection and were used to better inform the interpretation of the results (see Ulug \& Cohrs, 2017a for a similar strategy). After the participants finished their sorting, the researcher wrote down the numbers of the statements on a separate paper. At the end of the Q-sorting procedure, the participants were asked to complete a demographics questionnaire (e.g., age, gender, educational background, ethnicity, native language, how many languages they speak, where they were born, which nationality describes them better, and how long they have lived in Germany).

Insert Figure 1 


\section{KURDISH-TURKISH DIASPORA IN GERMANY}

\section{Analysis}

Q methodology includes a by-person factor analysis that is based on the correlations between the participants that are represented by Q-sorts in Q methodology. Similar Q-sorts that correlate significantly with each other are called a factor of Q-sorts (Shinebourne, 2009). Therefore, the analysis produces several factors of Q-sorts, with each factor representing a group of individuals with similar viewpoints (i.e., socially shared perspectives). In other words, the participants who have the same views load on the same factor (Webler, Danielson, \& Tuler, 2009).

PQMethod 2.35 (Schmolck, 2014) was used to analyze the data. PQMethod provides two factor analyses options: Centroid Factor Analysis (CFA) and Principal Components Factor Analysis (PCA). CFA focuses on commonality among Q sorts, not the particularities of individual sorts. PCA considers both particularities and commonalities (Stevens, 2002). In Q methodology, there are two options for factor rotation: Varimax and hand rotation. Varimax rotation allows the researcher to produce a simple structure, maximizing the eigenvalue for each factor (Stevens, 2002). Hand rotation helps to maximize the contrast between the factors. The order of factors was rearranged for presentation purposes so that the first three factors represented the "pro-Kurdish" viewpoint while the last one represented the "pro-Turkish" viewpoint. In this study, PCA and Varimax rotation were used, and the number of factors was decided based on four criteria suggested by Webler et al. (2009): a) simplicity (i.e., a solution with fewer factors is better than a solution with more factors), b) clarity (i.e., the more Q sorts load highly and uniquely on one factor, the better), c) distinctness ${ }^{1}$ (i.e., the lower the

\footnotetext{
${ }^{1}$ As the interpretations of the factors made sense, we chose a four-factor solution even though the correlations were high between the factors (see Uluğ \& Cohrs, 2017a for a similar strategy).
} 


\section{KURDISH-TURKISH DIASPORA IN GERMANY}

correlations between the idealized Q-sorts representing the factors, the better), and d) stability (i.e., certain subsets of participants load together across different solutions).

\section{Results}

In the results section, each factor or viewpoint will be explained based on the most agreed (i.e., statements sorted at $+3,+4$ or +5 ), most disagreed (i.e., statements sorted at $-3,-4$ or -5 ), and distinguishing statements (i.e., result of a statement on a factor is significantly different from any other factor; Akhtar-Danesh, Baumann, \& Cordingley, 2008). Some of the participants' comments about the statements will be included to help the reader contextualize the viewpoints.

In Q methodology, a "35-40\% or above would ordinarily be considered a sound solution on the basis of common factors" (Watts \& Stenner, 2005, p. 105). Four-factor solution was deemed optimal in terms of the criteria mentioned above. In total, these four factors explained $61 \%$ of the total amount of variance. Factor loadings in Q methodology indicate each participant's association with each of the identified perspective (Valenta \& Wigger, 1997). For example, a factor loading of 0.85 means that a participant's Q sort is highly correlated with this factor. In Q methodology, factor loadings can range from -1.00 to +1.00 as in other correlation coefficients (Valenta \& Wigger, 1997). In this study, twenty-nine out of 43 of the participants loaded clearly on one of the four factors with the remaining 14 participants not loading on any of the factors as they had multiple loadings on more than one factor. Thus, their view represented a combination of the perspectives.

Factor 1: Freedom for Öcalan Frame. Frame 1 had twelve defining Q sorts, with factor loadings ranging from .51 to .76 (see Table 1 for factor loadings) explaining $20 \%$ of the study variance. Three participants were women and nine men with ages ranging between 30 and 63 years $(M=44.5 ; S D=12.31)$ and having reported living in Germany between 10 and 47 years 


\section{KURDISH-TURKISH DIASPORA IN GERMANY}

$(M=25.70 ; S D=12.00)$. Frame 1 can be defined as a predominantly "Kurdish" view as almost all participants self-identified as Kurdish, except for three. Two identified as Turkish and one as Turkish-Kurdish.

In Frame 1, the participants did acknowledge that there is a Kurdish problem, and rejected that there is no problem of my fellow Kurdish brothers and sisters (no. 10; see Table 2 for $z$ scores of all statements) and did not see the PKK as creating this problem (no. 5). One participant stated, "If there is no Kurdish problem, then why are Kurds on the mountains?" The [Kurdish] problem was not seen as the PKK and terrorism problem (no. 18). For these participants, the PKK was not a terrorist organization (no. 23). For instance, one participant said, "the PKK and the terror are not the same things." According to these participants, the victims of the Kurdish conflict were the people living in the eastern region of Turkey (i.e., a region where Kurds are densely populated; no. 28).

Insert Table 2

Following Frame 1, the solutions lied in an independent Kurdistan and the release of the PKK leader, Öcalan (nos. 35 and 43). The participants' comments indicated that there is a strong emphasis on the PKK as its aim is increasing self-awareness among Kurds. According to the participant, "the PKK fighters are freedom fighters."

The participants rejected the following solutions suggesting that a renewed unification should be sought under the umbrella of Islam, and the PKK should lay down its weapons (nos. 33 and 39). For example, one participant explained her reason why the PKK should not lay down 


\section{KURDISH-TURKISH DIASPORA IN GERMANY}

the weapons: "If the TSK (Turkish Armed Forces) sustains this war, the PKK should not lay down its weapons [even though] it does not mean that I love weapons."

Factor 2: Nation-State Ideology and Democracy Frame. Frame 2 had five defining Q sorts with factor loadings from .57 to .84 and explained $12 \%$ of the study variance. Four participants were men and one woman with ages ranging from 40 to $58(M=48.60 ; S D=8.88)$ who reported living in Germany from 16 to 38 years $(M=25.00 ; S D=9.22)$. Frame 2 can also be defined as a predominantly "Kurdish" view because three participants identified as Kurdish and one identified as a world citizen and one as a Turkish.

In Frame 2, the problem was seen as a problem of democracy (no. 2). The causes of the problem were the assimilation policies and the nation-state ideology of Turkey (nos. 16 and 17). These participants did not believe that the PKK is a terrorist organization, and Kurds and Turks have the same rights in Turkey (nos. 23 and 25). For instance, one participant commented on statement 25 (i.e., Kurds and Turks have the same rights, I cannot understand what Kurds want): "This sentence is very nationalist, and it does not make sense. Turks are in all the elite positions, and they do not want Kurds to improve themselves because laboring Kurds makes them feel better." Finally, they also rejected that the Kurds are used by foreign powers (no. 29).

According to Frame 2, the solutions for the Kurdish conflict lied in deep-rooted democratization and the implementation of human rights (no. 32). The solution that suggests the Kurdish people should be educated was rejected in this factor (no. 42). Another solution that highlights the need for keeping the unitary state structure was rejected as well (no. 45).

In regard to the correlations between Q sorts, Frame 1 and 2 shared similar viewpoints, with a correlation of .59 (see Table 3 for correlations between factors). For example, in both frames, it was agreed that local administration should be strengthened (no. 38). However, there 


\section{KURDISH-TURKISH DIASPORA IN GERMANY}

were also some differences between these frames. For instance, Frame 2 did not recognize the importance of an independent Kurdistan, and only the participants in Frame 1 agreed that the PKK should not lay down its weapons (nos. 35 and 39).

\section{Insert Table 3}

Factor 3: Independence and Identity for Kurds Frame. Frame 3 had four defining sorts with factor loadings ranging from .56 to .77 and explained $12 \%$ of the study variance. Two participants were men, and two were women with ages ranging between 31 and 73 years $(M=$ 49.00; $S D=17.80)$ and having reported living in Germany from 10 to 42 years $(M=28.5 ; S D=$ 14.89). Frame 3 was held by two Kurdish and two Turkish participants.

In Frame 3, the Kurdish problem was viewed in terms of Kurdish identity, independence, and rights and freedom (nos. 7, 8, and 9), and it was accepted that there is a Kurdish problem (no. 10). According to Frame 3, the causes of the problem were the feudal structure in the region and the assimilation policy toward the Kurds (nos. 15 and 16). The idea that Kurds are used as pawns was rejected in this viewpoint (no. 29).

Following the third frame, the Kurdish conflict can be resolved through democratization and implementation of human rights, and an independent Kurdistan should be established (nos. 32 and 35). In Frame 3, the idea of a unifying Islamic umbrella was rejected, and the unitary state structure should be changed (nos. 33 and 45).

In general, Frame 1 and 3 had the highest level of correlations $(r=.60)$, with participants holding similar and different viewpoints in terms of solutions for the Kurdish conflict. For instance, both viewpoints believe that an independent Kurdistan should be established (no. 35). 


\section{KURDISH-TURKISH DIASPORA IN GERMANY}

However, Frame 1 did not support the idea that the PKK should lay down its weapons while Frame 3 did (no. 39) and Frame 3 criticized the feudal structure in the region.

There was also a similarity between Frame 2 and Frame $3(r=.58)$ in terms of moral judgments. Both frames did not see Kurds as pawns used by foreign powers (no. 29). However, those two frames identified the solution for the problem differently. For Frame 2, the problem can be solved through democratization and implementation of human rights (no. 32). Even though it seems that Frame 3 also endorses the democratization idea (although not as much stronger), the solution strongly lied in establishing an independent Kurdistan (no. 35).

Lastly, Frames 1, 2 and 3 have some similarities such as their shared negative view about the definition of the problem. For example, it is agreed that the problem is neither terrorism nor a Kurdish invasion problem but a Kurdish problem (nos. 1 and 11). They see the cause of the problem in the denial of the Kurdish identity for many years, and they all agree that a solution to the Kurdish problem includes the constitutional recognition of the Kurdish people and Kurdishlanguage broadcasting (nos. 13, 36, and 37). In all three frames, it is acceptable for the HDP to embrace PKK militants (no. 24). They all agree that the TSK's active counter-terrorism policy is not a solution to the problem (no. 46).

Factor 4: Terrorism, Economy and Foreign Power Frame. Frame 4 had eight defining sorts with factor loadings ranging from .54 to .78 and explained $17 \%$ of the study variance. Five participants were men, and three were women with ages ranging between 44 and 65 years $(M=$ $51.75 ; S D=8.26)$ and having reported living in Germany between 10 and 46 years $(M=36.75$; $S D=12.78)$. Frame 4 can be defined as a predominantly "Turkish" view as all participants identify as Turkish, except for two (one as Turkish-German and the second as Turkish and human). 


\section{KURDISH-TURKISH DIASPORA IN GERMANY}

These participants viewed the problem in terms of terrorism and held that it was created by the PKK (nos. 1 and 5). These participants did not define the status of Kurds in terms of colonization and the Kurdish problem in terms of an independence problem (nos. 3 and 8). They saw the PKK and the interventions of foreign powers (nos. 14 and 18) but not the denial of the Kurds or the assimilation policies toward Kurds (nos. 13 and 16) as the causes of the problem.

In this frame, the PKK was seen as a terrorist organization, and Kurds were seen as pawns used by the foreign powers (nos. 23 and 29). It was rejected that Turks have prejudice against Kurds (no. 30). For these participants, the problem can be solved by the PKK laying down its weapons and by economic development and an increase in job opportunities (nos. 34 and 39).

According to this viewpoint, an independent Kurdistan should not be established, Öcalan should not be released, and İmralı negotiations should not continue; none of these were viewed as agreeable solutions (nos. 35, 43 and 47). These participants also rejected the constitutional recognition of the Kurds (no. 36). For example, two participants argued that if the constitution recognizes Kurds, this recognition will divide Turkey. On the other hand, one participant commented on the statement, "Kurds should not have an identity card that shows one is Kurdish, but they should be accepted as Kurdish in society." Last, in line with seeing the problem as a foreign power problem, these participants saw America's interests in the region as a barrier to the solution of the problem (no. 53). However, they disagreed with the notion that the TSK does not want to finish this war (no. 50).

Factors 1 and 4 had the least similarities $(r=-.54)$; therefore, they had the highest conflict potential among the factors. For example, Frame 1 accepted the existence of the Kurdish problem and rejected the idea of a terrorism problem (no. 1). Frame 4, on the other hand, had the 


\section{KURDISH-TURKISH DIASPORA IN GERMANY}

opposite opinion about the same statements. However, in both frames, the victims of this problem were seen as the people in the Kurdish region (no. 28).

Moreover, Frames 2 and 4 had some viewpoints that distinguish them $(r=-.30)$. Frame 2 did not view that the Kurdish issue is created by the PKK (no. 5) and saw the nation-state ideology of Turkey as causes of the problem (no.17), but Frame 4 did not share these ideas. Both frames believed that both PKK should lay down its weapons (no.39) and that this problem has not been solved because of those who profit from the problem (no. 48).

Frame 3 and Frame 4 also showed some opposite viewpoints $(r=-.43)$. Frame 3 saw the problem as an independence problem, whereas Frame 4 did not (no. 8). However, there were points of agreement between these factors. For example, like Frame 3, the barrier to resolving the problem was seen in America's interest in the region (no. 53).

\section{Discussion}

The aim of the current study was to examine the perspectives of the Kurdish and Turkish diaspora living in Germany regarding the Kurdish conflict in Turkey. Findings highlighted four conflict frames among the Kurdish and Turkish diaspora.

The first frame, held predominantly by Kurds, shows great support for the PKK and its leader, Öcalan. One potential reason for supporting the PKK might be that most of the participants in this frame left Turkey at least 25 years ago, after the military coup in Turkey in 1980 when the conflict was very hot between the Turkish state and the PKK motivating large numbers to leave. It is possible that the participants might have had traumatic experiences during this time, and the reasons they moved to Germany might have been political because of the high pressure on Kurds in Turkey. The past experiences of violence in one's country of origin can still 


\section{KURDISH-TURKISH DIASPORA IN GERMANY}

be meaningful for people, and it does not stay only in the country of origin but also appears in the places to which they migrate (Martinovic, Jetten, Smeekes, \& Verkuyten, 2017).

Reflecting the heterogeneity within the Kurdish diaspora, Frame 2, also held predominantly by Kurds, focuses on the ideology of the nation-state and the role of democracy. Different from Frame 1, this viewpoint mostly focuses on democracy rather than an independent Kurdistan or the PKK. It shows that not everyone in the Kurdish diaspora supports the PKK or the idea of an independent Kurdistan (Baser \& Swain, 2008). This viewpoint is mostly against Turkey's nation-state policies and supports democratic steps for ending the Kurdish conflict by demanding more equality in society (e.g., in education). So, this viewpoint focuses on the solutions within the borders of Turkey. It is also important to highlight that the participants did not describe a certain meaning of democracy and the implementation of human rights in this frame. The meanings of democracy and implementation of human rights might be different for different groups (Carlin, 2018), so we do not know what these democratic solutions entail for these participants in general.

The third frame, shared both by Kurds and Turks, focuses on the Kurdish identity and independence for Kurds. As Kurdish identity has been denied by the Turkish state, many Kurds demand constitutional recognition of their identity as well as their cultural and linguistic rights (Gunes, 2012). Hence, it is understandable that the Kurdish participants demand the recognition of Kurdish identity as well as an independent Kurdistan because they want to preserve their identity. This frame is distinguished from the other frames because it includes Turkish participants of different age groups that also support an independent Kurdistan. What these Turkish participants have in common is that they are Alevis, ${ }^{2}$ belonging to a religious minority

\footnotetext{
${ }^{2}$ Author one met them at the Alevi organization in Germany.
} 


\section{KURDISH-TURKISH DIASPORA IN GERMANY}

group in Turkey. As the second-largest belief in Turkey after Sunni Islam, Alevis have faced instances of mass violence several times in Turkey, especially by individuals supporting rightwing policies who believe that Alevis have a close affiliation with left ideology (KarakayaStump, 2017). Research has found that minority groups within the United States (Blacks and Latinos) show empathy for non-White immigrant groups (Sirin, Valentino, \& Villalobos, 2016). We argue that the oppression of Alevi people might have created empathy for another oppressed group, Kurds, in this diaspora context.

The fourth frame, shared predominantly by Turkish participants, considers the role of terrorism, the economy, and foreign powers. This viewpoint can be described as a nationalistic conflict frame (Uluğ \& Cohrs, 2016). In this frame, the existence of the Kurdish conflict is denied, and not surprisingly, the PKK is blamed for being the root of terrorism in Turkey. However, the participants are more critical about the policies of the AKP government rather than the TSK. Some of these participants commented that Kurdish rights, such as a recognized Kurdish identity, should have been granted earlier. The other important aspect of this frame concerns the lack of good economic conditions and access to employment opportunities.

Our study shows that each diaspora group might have their own unique position when they interpret the Kurdish conflict (e.g., Frame 1 and 2). For Frame 1, the solutions involve an independent Kurdistan, and the release of the PKK leader, Öcalan. The participants in Frame 1 do not see a unified national future with Turks. For Frame 2, on the other hand, the solutions for the Kurdish conflict involve deep-rooted democratization and the implementation of human rights. However, participants in Frame 2 do see a unified national future with Turks as independent Kurdistan is not something they demand for. Furthermore, Frame 1 does not support the idea that the PKK should lay down its weapons while Frame 2 does. This is an important 


\section{KURDISH-TURKISH DIASPORA IN GERMANY}

distinction between these factors because the PKK is one of the important representatives of the Kurdish people in this conflict, and it plays a crucial role in conflict resolution and peacebuilding processes (e.g., Turkish government's peace negotiations with the PKK in Oslo). Due to ongoing clashes between the PKK and Turkish Armed Forces, approximately 40,000 people lost their lives in the conflict. The Kurds in Europe have an essential role in the conflict by providing financial support for the PKK (Gunes, 2013). This support may increase the violence in the conflict region. Therefore, these different opinions on armed struggle may lead to conflict or support for the peace process in the conflict region.

Some members of the Turkish diaspora share similar solutions with the Kurdish diaspora, such as supporting an independent Kurdistan (e.g., Frame 1 and Frame 3). As mentioned above, for Frame 1, the solutions lied in an independent Kurdistan and the release of the PKK leader, Öcalan. In Frame 3, Kurdish and Turkish participants suggested that the Kurdish conflict can be resolved through democratization and the implementation of human rights, as well as the establishment of an independent Kurdistan. While Kurdish support for an independent Kurdistan might increase conflict in the homeland (Uluğ \& Cohrs, 2016), support for an independent Kurdistan by the Turkish diaspora may also decrease tension between Kurds and Turks in the diaspora. Even though some Turkish participants support an independent Kurdistan, we should also note that some Kurdish participants do not support an independent Kurdistan. As socialpsychology has tended to focus on the two parties to a conflict as if they were two homogenous groups (e.g., "ingroup” and “outgroup"; see Uluğ \& Cohrs, 2019 for a discussion), our results speak to the importance of investigating within-group differences, particularly differences in conflict frames within conflicting parties. 


\section{KURDISH-TURKISH DIASPORA IN GERMANY}

Furthermore, both Frame 2 and Frame 3 support democratization but, Frame 2 strongly opposes the nation-state ideology while Frame 3 presents a border solution by suggesting an independent Kurdistan. Sharing similar difficulties such as isolation, discrimination, and the loss of identity in the hostland may enable Kurds and Turks to have empathy for each other. This can also be explained by inclusive victim consciousness, which is a belief that others have also suffered in a similar way as the ingroup. A study found that minority groups with different victimization experiences, such as war and direct and structural violence, showed solidarity and positive attitudes towards other minority groups because they believe they have shared similar victimization experiences (Vollhardt, Nair, \& Tropp, 2016). However, we should note that those similarities and differences cannot be generalized about diaspora communities' ethnic identity due to the small sample and purposive sampling strategy employed in this study (Thomas \& Bass, 1993).

\section{Relationship to the Previous Study: Conflict in Homeland and Hostland}

Participants in the past study (Uluğ \& Cohrs, 2016) and the current study predominantly identified either as Kurdish or Turkish, and were fluent in the Turkish language. However, the participants were significantly younger $(M=30.00, S D=10.30)$ in Uluğ and Cohrs's (2016) study than the participants in the current study $(M=47.58, S D=10.77) ; t(112)=-8.68, p<$ $.001)$. The age differences may explain the differences and similarities in the two studies. For instance, Uluğ and Cohrs (2016) suggest that having fresh memories and witnessing the misbehavior of the Turkish state may lead younger Kurds to demand an independent Kurdistan. However, our results show that older Kurdish people in the diaspora also demand an independent Kurdistan (see Table 4 for all viewpoints in both studies). One possible explanation might be that 


\section{KURDISH-TURKISH DIASPORA IN GERMANY}

the past experiences of violence can still be traumatic and meaningful for older Kurds in the diaspora.

Insert Table 4

There were a number of differences, however, between the current findings and those of Uluğ and Cohrs (2016). For instance, one important difference concerned the terrorism and foreign power frame. Uluğ and Cohrs (2016) interpreted the terrorism and foreign power frame as an expression of the Turkish nationalist perspective on the Kurdish conflict. In the current study, those who supported this frame included participants who are not against education in the Kurdish language. While this support of Kurdish cultural and educational autonomy may have been limited, it is remarkable in the context of the Turkish nationalist perspective. For instance, one participant said, "Kurds should learn their language. If someone tells me 'do not speak Turkish in Germany,' that would make me angry." The Turkish diaspora might experience language discrimination in Germany, and this might help them empathize with Kurdish people in the home country. As Uluğ and Cohrs (2016) mention in their study, this terrorism and foreign power frame still might lead to higher levels of conflict because of the failure to acknowledge Kurdish concerns by focusing more on Turkish concerns and seeing the Kurdish people's demands as a threat to the Turkish state.

A second difference concerns the independence and identity for Kurds and the rights, freedom, and democracy frame. While Frame 3 is shared by Kurds and Turks in both studies, in 


\section{KURDISH-TURKISH DIASPORA IN GERMANY}

the current study, the Kurdish problem is seen as an independence and identity problem. In Uluğ and Cohrs's (2016) study, in contrast, the idea of an independent Kurdistan was rejected in the right, freedom, and democracy frame (Frame 3; see Table 4). Diaspora and homeland citizens likely have a different approach to questions of ethnic and national identity (Sahin, 2002). Their identity is shaped by their experience both in their hostland and homeland. This includes how they feel about their group and express satisfaction about their own group's needs (Tajfel, 1974; Tajfel \& Turner, 1986). When a group's basic identity needs are denied, intergroup conflicts can easily break out (Fisher, 2006). Shared identities in a hostland may also play a key role in how diaspora groups understand the conflict situation in the homeland. New goals in a host society can construct cooperative relationships for a peaceful society (Bar-Tal, 2000). Similar to Uluğ and Cohrs's (2016) study, in Frame 3, the recognition of the rights to education, broadcasting in the Kurdish language, and deep-rooted democratization and human rights are required for the solution of the Kurdish conflict. In a nutshell, even though there are some similarities between Frame 3 in the current study and Frame 3 in Uluğ and Cohrs's (2016) study, the implications of these differences related to support for an independent Kurdistan are far-reaching.

Third, in Uluğ and Cohrs’s (2016) study, only one predominantly Kurdish frame emerged. In the current study, on the other hand, two predominantly Kurdish frames emerged. In our study, one of the Kurdish frames (Frame 1) had several similarities with Uluğ and Cohrs's (2016) study in terms of supporting an independent Kurdistan (Frame 4). Still, it opposes the idea that the PKK should lay down its weapons. However, Frame 2 in the current study has opposite viewpoints for the same solution strategies. These differences may be based upon the current state of the conflict. While Uluğ and Cohrs (2016) conducted their study during a relatively calm period of the conflict (i.e., the peace process period in 2013) in Turkey, the 


\section{KURDISH-TURKISH DIASPORA IN GERMANY}

current research was completed after the failure of the peace process and in the midst of continued conflict in 2018. It is an important time to consider if and how the peace process changed peoples' perspectives. For instance, after the peace process, Kurdish people reexperienced hot conflict in Turkey; however, not all Kurdish diaspora members demanded an armed struggle against the Turkish Army during this period. As mentioned above, there is support for the PKK by some Kurdish participants in the diaspora; yet, there is no clear evidence that these participants support continued armed struggle. Therefore, based on our findings, we believe that people, especially Kurdish people in the diaspora, might desire a peaceful negotiation instead of an armed struggle.

\section{Implications of Diaspora's Role in Conflict Resolution}

Our findings give some insights into examining diaspora communities in non-conflict countries. We believe the findings from the current study have important implications for policymakers, as understanding the perspective of diasporas can help to inform efforts to identify tangible solutions to conflict. Interestingly, Turkish participants in Germany did not totally reject the idea of the right to education in the Kurdish language in Turkey. This support might help reduce another aspect of conflict: Kurdish assimilation in Turkey. In line with this finding, another study found that when Turkish participants recognized the discrimination that Kurds experience, they supported Kurdish language rights more (Çelebi, Verkuyten, \& Smyrnioti, 2016). Living in a diaspora context where there is discrimination against Turks, their identity and rights may have helped some Turks understand Kurds' discrimination experiences in the homeland. Moreover, a previous study found that a common identity may also reduce discrimination between the groups (Gaertner, Mann, Dovidio, Murrell, \& Pomare, 1990). Having a common identity (i.e., German identity or diaspora identity) may help Turks understand Kurds' 


\section{KURDISH-TURKISH DIASPORA IN GERMANY}

experiences, change their perceptions about Kurds and break down the barriers between the groups.

Because of the nature and complexity of the conflict, studies on peacebuilding should focus on diasporas to grasp different approaches to conflict resolution. Diaspora and homeland citizens often have different approaches to questions of territory (Shain, 2002). This may be reflected in the nation-state ideology; in the current study, the Kurdish diaspora participants did not demand an independent Kurdistan, whereas, in the previous Uluğ and Cohrs (2016) study, Kurdish people living in Turkey demanded an independent Kurdistan in independence frame.

\section{Limitations and Suggestions for Future Research}

There are several limitations of the current study. In terms of the study materials, Q study statements were not directly collected from the diaspora population in Germany. As mentioned earlier, these statements were collected in Turkey from sources such as articles, newspapers, and political party programs. Therefore, the current statements might create some potential limitations for this study. The participants' ability to disclose their viewpoints on the problem may have been limited by the available scope of the statements. Further research could aim to augment the scope of available statements, such as diaspora identity, to better understand how the diaspora members perceive the conflict in relation to their identity. Also, it would be important to add new items to understand how power dynamics play a role between/within diaspora and homeland as well as to include participants from similar educational and age backgrounds to compare with the previous study.

In addition, future research might also focus on how the participants perceive democracy. Understandings of democracy might differ between the participants when it comes to using democracy to resolve the Kurdish conflict (Uluğ \& Cohrs, 2017a). A qualitative study might help 


\section{KURDISH-TURKISH DIASPORA IN GERMANY}

us explore the meaning of democratization in conflict contexts from the eyes of different ethnic groups thereby allowing us to identify possible barriers to the peace process (see also Carlin, 2018). Moreover, one can also follow up on how the participants react to a changing conflict. People's reactions towards the conflict may be different during a peace process and when the peace process fails. For example, Kurdish and Turkish people reacted to intergroup tension differently during high- vs. low-intensity conflict (Bilali, Çelik, \& Ok, 2014). Therefore, future studies should also take these dynamics into account when conducting research in a conflict context.

Future studies may also focus on using these different frames to explore other conflicts such as the Palestine-Israeli and the Northern Irish conflict. For example, Uluğ, Lickel, Leidner, and Hirshberger (2020) tested the generalizability of conflict frames in parallel studies in the context of Turkish-Kurdish (Study 1) and Israeli-Palestinian relations (Study 2) among majority group members (Turks and Jewish Israelis, respectively). They found that conflict frames may work in similar ways in different conflict contexts in terms of shaping people's support for peace and conflict. Although the statements used in the current study were appropriate to investigate the current politics of the Kurdish conflict in the diaspora community, future studies should add more diaspora related items to be able to examine the unique role diasporas play in conflict contexts.

\section{Conclusion}

While mass migration increases day by day, the number of parties in conflicts increases as well. Diaspora communities are one of those conflict parties that can have an important influence on homeland and hostland countries. The absence of diaspora studies on conflict frames is a barrier to comprehensively understanding conflicts. Our results highlight the 


\section{KURDISH-TURKISH DIASPORA IN GERMANY}

importance of studying how diaspora groups perceive conflicts and raise important questions about diaspora communities that need to be explored systematically in social and political psychology. Building on previous research utilizing the Q methodology, our study indicates that there are differences and similarities between the diaspora community in Germany and conflicting parties in Turkey. We hope that this study will contribute to the literature by including the diaspora viewpoints in conflict resolution and peacebuilding processes. 


\section{KURDISH-TURKISH DIASPORA IN GERMANY}

\section{References}

Adamson, F. (2002). Mobilizing for the transformation of home: Politicized identities and transnational practices. In N. Al-Ali \& K. Khalid (Eds.), New approaches to immigration? (pp. 155-169). London, UK: Routledge.

Akhtar-Danesh, N., Baumann, A., \& Cordingley, L. (2008). Q-Methodology in nursing research: A promising method for the study of subjectivity. Western Journal of Nursing Research, 30(6), 759-773. http://dx.doi.org/10.1177/0193945907312979

Amman, B. (2005). Kurds in Germany. In Ember M., Ember C.R., \& Skoggard I (Eds.), Encyclopedia of Diasporas (pp.101-1019). Boston, MA: Springer.

Aydın, Y. (2016). Turkish diaspora policy: Transnationalism or long-distance nationalism? In I. Sirkeci \& B. Pusch (Eds.), Turkish Migration Policy (pp. 169-180). London, UK: Transnational Press.

Bar-Tal, D. (2007). Sociopsychological foundations of intractable conflicts. American Behavioral Scientist, 50(11), 1430-1453. http://dx.doi.org/10.1177/0002764207302462

Bar-Tal, D. (2000). From intractable conflict through conflict resolution to reconciliation: Psychological analysis. Political Psychology, 21(2), 351-365. https://doi.org/10.1111/0162-895X.00192

Baser, B. (2017). Intricacies of engaging diasporas in conflict resolution and transitional justice: The Kurdish diaspora and the peace process in Turkey. Civil Wars, 19(4), 470-494. https://doi.org/10.1080/13698249.2017.1396528

Baser, B. (2017). Tailoring strategies according to ever-changing dynamics: The evolving image of the Kurdish diaspora in Germany. Terrorism and Political Violence, 29(4), 674-69. https://doi.org/10.1080/09546553.2015.1060226 


\section{KURDISH-TURKISH DIASPORA IN GERMANY}

Baser, B., \& Swain, A. (2008). Diaspora as peacemakers: Third party mediation in homeland conflicts. International Journal on World Peace, 25(3), 7-28.

Bercovitch, J. (2007). Diasporas in conflict: Peace-makers or peace-wreckers? In H. Smith \& P. Stares (Eds.), A neglected relationship: Diasporas and conflict resolution (pp. 17-38). Tokyo, Japan: United Nations University Press.

Bilali, R., Çelik, A., B., \& Ok, E. (2014). Psychological asymmetry in minority-majority relations at different stages of ethnic conflict. International Journal of Intercultural Relations, 43, 253-264. http://doi.org/10.1016/j.ijintrel.2014.09.002

Brown, M. (2004). Illuminating patterns of perception: An overview of Q methodology (No. CMU/SEI-2004-TN-026). Carnegie-Mellon Univ: Pittsburgh PA Software Engineering Inst.

Carlin, R. E. (2018). Sorting out support for democracy: A Q-method study. Political Psychology, 39(2), 399-422. https://doi.org/10.1111/pops.12409

Casier, M. (2011). Neglected middle men? Gatekeepers in homeland politics. Case: Flemish nationalists' receptivity to the plight of Turkey's Kurds. Social Identities: Journal for the Study of Race, Nation and Culture, 17(4), 501-521.

https://doi.org/10.1080/13504630.2011.587305

Chapin, W. D. (1996). The Turkish diaspora in Germany. Diaspora: A Journal of Transnational Studies, 5(2), 275-301. https://doi.org/10.1353/dsp.1996.0015

Cuppen, E., Breukers, S., Hisschemöller, M., \& Bergsma, E. (2010). Q methodology to select participants for a stakeholder dialogue on energy options from biomass in the Netherlands. Ecological Economics, 69(3), 579-591. http://dx.doi.org/10.1016/j.ecolecon.2009.09.005 


\section{KURDISH-TURKISH DIASPORA IN GERMANY}

Çelebi, E., Verkuyten, M., \& Smyrnioti, N. (2016). Support for Kurdish language rights in Turkey: The roles of ethnic group, group identifications, contact, and intergroup perceptions. Ethnic and Racial Studies, 39(6), 1034-1051. https://doi.org/10.1080/01419870.2015.1103881

Çelik, A. B., \& Blum, A. (2007). Track II interventions and the Kurdish question in Turkey: An analysis using a theories of change approach. International Journal of Peace Studies, 12(2), 51-81.

Entman, R. M. (1993). Framing: Toward clarification of a fractured paradigm. Journal of Communication, 43(4), 51-58. http://doi.org/10.1111/j.1460-2466.1993.tb01304.x

Fisher, R. J. (2006). Intergroup conflict. In M. Deutsch, P. T. Coleman, \& E. C. Marcus (Eds.), The handbook of conflict resolution: Theory and practice (pp. 176-196). San Francisco, CA: Jossey-Bass.

İçduygu, A. (2012). 50 years after the Labour Recruitment Agreement with Germany: The consequences of emigration for Turkey. Perceptions, 17, 11-36.

Gaertner, S. L., Mann, J. A., Dovidio, J. F., Murrell, A. J., \& Pomare, M. (1990). How does cooperation reduce intergroup bias? Journal of Personality and Social Psychology, 59(4), 692-704.

Gunes, C. (2012). Unblocking the Impasse in Turkey's Kurdish Question. Peace Review. Peace Review: Journal of Social Justice, 24, 462-469.

https://doi.org/10.1080/10402659.2012.732449

Gunes, C. (2013). Explaining the PKK's mobilization of the Kurds in Turkey: Hegemony, myth, and violence. Ethnopolitics, 12(3), 247-267.

https://doi.org/10.1080/17449057.2012.707422 


\section{KURDISH-TURKISH DIASPORA IN GERMANY}

Jeong, H. (2010). Conflict management and resolution. New York, NY: Routledge.

Karakaya-Stump, A. (2017). The AKP, sectarianism, and the Alevis' struggle for equal rights in Turkey. National Identities, 20(1), 53-67.

https://doi.org/10.1080/14608944.2016.1244935

Koinova, M. (2009). Conditions and timing of moderate and radical diaspora mobilization:

Evidence from conflict-generated diasporas. Working paper, No.9. Global Migration and Transnational Politics. Retrieved from

https://www.gmu.edu/centers/globalstudies/publications/gmtpwp/gmtp_wp_9.pdf

Martinovic, B., Jetten, J., Smeekes, A., \& Verkuyten, M. (2017). Collective memory of a dissolved country: Group-based nostalgia and guilt assignment as predictors of interethnic relations between diaspora groups from former Yugoslavia. Journal of Social and Political Psychology, 5(2), 588-607. https://doi.org/10.5964/jspp.v5i2.733

Memcutek, Z, S., \& Baser, B. (2018). Mobilizing diasporas: Insights from Turkey's attempts to reach Turkish citizens abroad. Journal of Balkan and Near Eastern Studies, 20(1), 86105. https://doi.org/10.1080/19448953.2017.1375269

Østergaard-Nielsen, E, K. (2003). Transnational politics: Turks and Kurds in Germany. New York, NY: Routledge.

Ozkahraman, C. (2017). Failure of peace talks between Turkey and the PKK: Victim of traditional Turkish policy or of geopolitical shifts in the Middle East? Contemporary Reviews of the Middle East, 4(1), 50-66. https://doi.org/10.1177/2347798916681332

Ozsoy, H. (2013). Introduction: the Kurds' ordeal with Turkey in a transforming Middle East. Dialectical Anthropology, 37, 103-111. https://doi.org/10.1007/s10624-013-9306-1 


\section{KURDISH-TURKISH DIASPORA IN GERMANY}

Pirkkalainen, P. \& Adbile, M. (2009). The diaspora-conflict-peace-nexus: A literature review. Diaspeace Working Paper, No, 1. Retrieved from

Roth, A. (2015). The role of diaspora in conflict. Journal of International Affairs, 68(2), 289301.

Schmolck, P. (2014). PQMethod 2.35 [computer software]. Retrieved from http://schmolck.org/qmethod/

Shain, Y. (2002). The role of diasporas in conflict perpetuation or resolution. SAIS Review, 22(2), 115-144. https://doi.org/10.1353/sais.2002.0052

Shain, Y., \& Barth, A. (2003). Diasporas and international relations theory. International Organization, 57(3), 449-479. https://doi.org/10.1017/S0020818303573015

Shinebourne, P. (2009). Using Q method in qualitative research. International Journal of Qualitative Methods, 8, 93-97. https://doi.org/10.1177/160940690900800109

Sirin, C. V., Valentino, N. A., \& Villalobos, J. D. (2016). Group empathy in response to nonverbal racial/ethnic cues: A national experiment on immigrant policy. American Behavioral Scientist, 60(14), 1676-1697. https://doi.org/10.1177/0002764216676246

Smith, H. (2007). Diasporas in international conflict. In H. Smith \& P. Stares (Eds.), Diasporas in conflict: Peace-makers or peace-wreckers? (pp. 3-16). Tokyo, Japan: United Nations University Press.

Spear, J. (2006). The potential of diaspora groups to contribute to peace building: A scoping paper. Paper presented at the International Studies Association Conference, San Diego, California. 


\section{KURDISH-TURKISH DIASPORA IN GERMANY}

Staub, E. (2018). Preventing violence and promoting active bystandership and peace: My life in research and applications. Peace and Conflict: Journal of Peace Psychology, 24(1), 95111. https://doi.org/10.1037/pac0000301

Stevens, J. (2002). Applied multivariate statistics for the social sciences (4th ed.). Mahwah, NJ: Erlbaum.

Tajfel, H. (1974). Social identity and inter-group behavior. Social Science Information, 13(2), 65-93. https://doi.org/10.1177/053901847401300204

Tajfel, H., \& Turner, J. C. (1986). The social identity theory of inter-group behavior. In S. Worchel, \& W. Austin (Eds.), Psychology of inter-group relations (pp. 7-24). Chicago, IL: Nelson Hall.

Thomas, D. B., \& Baas, L. R. (1993). The issue of generalization in Q methodology: "Reliable schematics" revisited. Operant Subjectivity, 16, 18-36.

Uluğ, Ö. M., \& Cohrs, J. C. (2016). An exploration of lay people's Kurdish conflict frames in Turkey. Peace and Conflict: Journal of Peace Psychology, 22(2), 109-119. http://dx.doi.org/10.1037/pac0000165

Uluğ, Ö. M., \& Cohrs, J. C. (2017a). “Who will resolve this conflict if politicians don’t?”: Understandings of the Kurdish conflict among members of parliament in Turkey. International Journal of Conflict Management, 28(2), 245-266. http://dx.doi.org/10.1108/IJCMA-10-2015-0071

Uluğ, Ö. M., \& Cohrs, J. C. (2017b). How do experts differ from politicians in understanding a conflict? A comparison of track I and track II actors. Conflict Resolution Quarterly, 35(2), 147-172. https://doi.org/10.1002/crq.21208 


\section{KURDISH-TURKISH DIASPORA IN GERMANY}

Uluğ, Ö. M., Lickel, B., Leidner, B., \& Hirshberger, G. (2020). How do conflict narratives shape conflict- and peace-related outcomes among majority group members? The role of competitive victimhood in intractable conflicts. Group Processes and Intergroup Relations. Advance Online Publication. https://doi.org/10.1177/136843022091577

Uluğ, Ö. M., Odağ, Ö., Cohrs, J. C., \& Holtz, P. (2017). Understanding the Kurdish conflict through the eyes of Kurds and Turks: New conflict reflections from lay people in Turkey. International Journal of Conflict Management, 28(4), 483-508. https://doi.org/10.1108/IJCMA-05-2016-0035

Uluğ, Ö. M., \& Cohrs, J. C. (2019). Examining the ethos of conflict by exploring lay people's representations of the Kurdish conflict in Turkey. Conflict Management and Peace Science, 36(2), 169-190. https://doi.org/10.1177/0738894216674969

Valenta, A. L., \& Wigger, U. (1997). Q-methodology: Definition and application in health care informatics. Journal of the American Medical Informatics Association: JAMIA, 4(6), 501-510. https://doi.org/10.1136/jamia.1997.0040501

Vollhardt, J. R., Nair, R., \& Tropp, L. R. (2016). Inclusive victim consciousness predicts minority group members' support for refugees and immigrants. Journal of Applied Social Psychology, 46(6), 354-368. https://doi.org/10.1111/jasp.12368

Watts, S., \& Stenner, P. (2005). Doing Q methodology: Theory, method and interpretation. Qualitative Research in Psychology, 2(1), 67-91. http://dx.doi.org/10.1191/1478088705qp022oa

Watts, S. \& Stenner, P. (2012). Doing Q methodological research: Theory, method and interpretation. London, UK: Sage. 


\section{KURDISH-TURKISH DIASPORA IN GERMANY}

Webler, T., Danielson, S., \& Tuler, S. (2009). Using Q method to reveal social perspectives in environmental research. Greenfield, MA: Social and Environmental Research Institute.

Wohl, M. J. A., King, M., \& Taylor, D. M. (2014). Expressions of political practice: Collective angst moderated politicized collective identity to predict support for political protest (peaceful or violent) among diaspora group members. International Journal of Intercultural Relations, 43, 114-125. http://doi.org/10.1016/j.ijintrel.2014.08.020

Yuksel-Pecen, A. S. (2018). Representation of terror and ethnic conflict in the Turkish press: An analysis of the peace process in Turkey. Middle East Critique, 27(2), 207-219. https://doi.org/10.1080/19436149.2018.1443848 


\section{KURDISH-TURKISH DIASPORA IN GERMANY}

Table 1

Factor Loadings and Participants Characteristics.

\begin{tabular}{|c|c|c|c|c|c|c|c|c|c|c|c|}
\hline ID & F1 & $\mathrm{F} 2$ & F3 & $\mathrm{F} 4$ & $\begin{array}{l}\text { Identity/ } \\
\text { Language }\end{array}$ & $\begin{array}{c}\text { Gend } \\
\text { er }\end{array}$ & Age & Education & City & $\begin{array}{l}\text { Citizen } \\
\text { of the } \\
\text { country }\end{array}$ & $\begin{array}{l}\text { Years in } \\
\text { Germany }\end{array}$ \\
\hline 1 & .54 & .11 & .62 & -.15 & $\mathrm{~K} / \mathrm{K}$ & $\mathrm{F}$ & 49 & HS & Dersim & Ger & 23 \\
\hline 2 & -.05 & -.10 & -.07 & $.64 X$ & $\mathrm{~T} / \mathrm{T}$ & M & 63 & Bach & Maraş & WC & 39 \\
\hline 3 & $.55 X$ & .35 & .23 & -.42 & $\mathrm{~K} / \mathrm{K}$ & M & 47 & Prim & Urfa & Holland & 12 \\
\hline 4 & .45 & .45 & .24 & -.52 & $\mathrm{~K} / \mathrm{K}$ & M & 52 & Prim & Urfa & $\mathrm{DC}$ & 25 \\
\hline 5 & .52 & .52 & .21 & -.38 & $\mathrm{~K} / \mathrm{K}$ & M & 44 & Bach & Konya & $\mathrm{O}$ & 11 \\
\hline 6 & $.59 X$ & .31 & .39 & -.40 & $\mathrm{~K} / \mathrm{K}$ & M & 63 & Prim & Kars & Tur & 47 \\
\hline 7 & $.55 X$ & .12 & .06 & -.49 & $\mathrm{~K} / \mathrm{K}$ & M & 47 & Prim & Urfa & Ger & 27 \\
\hline 8 & .30 & .16 & $.77 X$ & -.24 & $\mathrm{~K} / \mathrm{K}$ & M & 31 & HS & Urfa & Ger & 10 \\
\hline 9 & .46 & .42 & .25 & -.57 & $\mathrm{~K} / \mathrm{K}$ & M & 50 & HS & Şırnak & Tur & 24 \\
\hline 10 & .16 & .43 & .10 & .32 & $\mathrm{~T} / \mathrm{T}$ & $\mathrm{F}$ & 28 & HS & İzmir & Ger & 28 \\
\hline 11 & $.68 X$ & .44 & .03 & -.16 & $\mathrm{~K} / \mathrm{K}$ & M & 35 & HS & Mardin & Tur & 25 \\
\hline 12 & -.01 & -.11 & -.55 & $.56 X$ & $\mathrm{~T} / \mathrm{T}$ & M & 47 & HS & N/A & Tur & 45 \\
\hline 13 & .40 & .24 & $.63 X$ & -.38 & $\mathrm{~K} / \mathrm{K}$ & M & 73 & Bach & Urfa & Tur & 23 \\
\hline 14 & $.64 X$ & .15 & .31 & -.48 & $\mathrm{~K} / \mathrm{K}$ & M & 55 & $\mathrm{Sec}$ & Horosan & Ger & 25 \\
\hline 15 & $.73 X$ & .11 & .14 & -.26 & $\mathrm{~K} / \mathrm{K}$ & $\mathrm{F}$ & 30 & $\mathrm{Sec}$ & Urfa & Tur & 10 \\
\hline 16 & .24 & $.57 X$ & .25 & -.10 & $\mathrm{~K} / \mathrm{K}$ & M & 58 & Bach & Dersim & Ger & 38 \\
\hline 17 & .31 & $.67 X$ & .12 & -.40 & $\mathrm{~K} / \mathrm{K}$ & M & 58 & HS & N/A & Ger & 30 \\
\hline 18 & $.76 X$ & .11 & -.00 & -.08 & $\mathrm{~T}-\mathrm{K} / \mathrm{T}$ & M & 54 & HS & Kars & $\mathrm{DC}$ & 46 \\
\hline 19 & .59 & .02 & .56 & -.01 & Internat./T & $\mathrm{F}$ & 45 & Bach & N/A & DC & 15 \\
\hline
\end{tabular}


KURDISH-TURKISH DIASPORA IN GERMANY

$\begin{array}{cccccccccccc}20 & .36 & .41 & .24 & -.51 & \mathrm{~K} / \mathrm{K} & \mathrm{F} & 53 & \text { Bach } & \text { Dersim } & \text { Ger } & 23 \\ 21 & .43 & .36 & .14 & .13 & \text { Human/T } & \mathrm{M} & 63 & \text { HS } & \text { İzmir } & \text { Tur } & 30 \\ 22 & -.18 & -.25 & -.06 & . \mathbf{6 4 X} & \mathrm{T} / \mathrm{T} & \mathrm{F} & 52 & \text { Prim } & \text { N/A } & \text { Tur } & 25 \\ 23 & -.24 & .01 & -.07 & . \mathbf{7 7 X} & \mathrm{T} / \mathrm{T} & \mathrm{F} & 44 & \text { HS } & \text { N/A } & \text { Tur } & 44 \\ 24 & -.30 & -.13 & -.15 & . \mathbf{7 8 X} & \mathrm{T} / \mathrm{T} & \mathrm{M} & 45 & \text { HS } & \text { N/A } & \text { Tur } & 45 \\ 25 & .13 & .84 X & .26 & -.06 & \mathrm{~K} / \mathrm{T} & \mathrm{F} & 41 & \text { Bach } & \text { Van } & \text { Ger } & 17 \\ 26 & .36 & .31 & .34 & -.10 & \mathrm{~K} / \mathrm{K} & \mathrm{F} & 36 & \text { Bach } & \text { Ağr1 } & \text { Ger } & 12\end{array}$

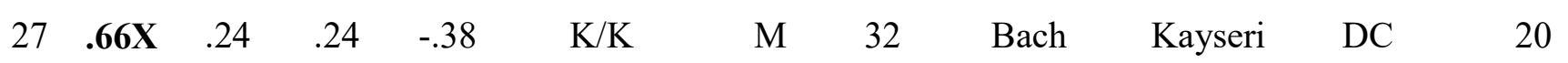

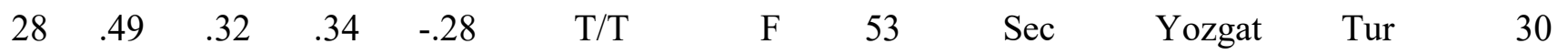

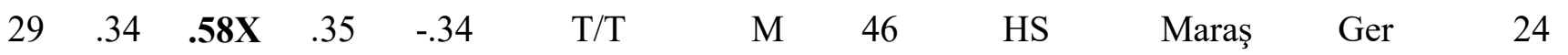

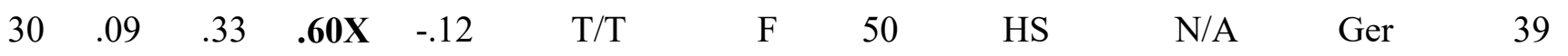

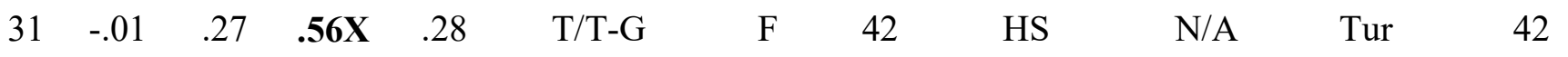

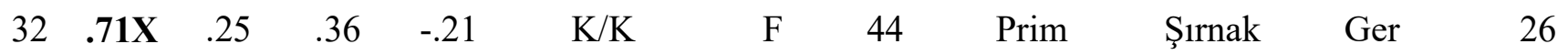

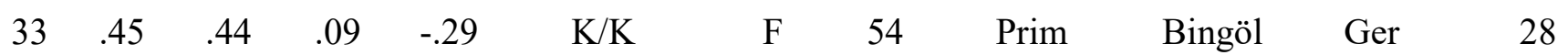

$\begin{array}{llllllllllll}34 & .52 & .32 & .52 & -.34 & \mathrm{WC} / \mathrm{K} & \mathrm{M} & 57 & \mathrm{HS} & \text { Maraş } & \text { Ger } & 27\end{array}$

$\begin{array}{llllllllll}35 & \mathbf{5 4 X} & .25 & .31 & -.29 & \mathrm{~T} / \mathrm{T} & \mathrm{M} & 63 & \text { Bach } & \text { Adana }\end{array}$

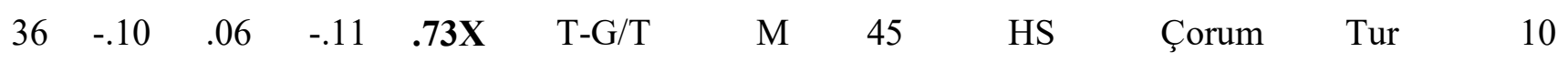

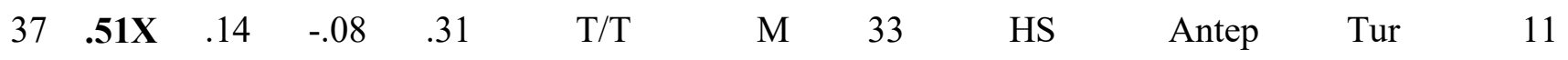

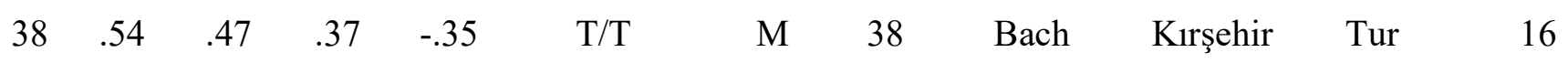

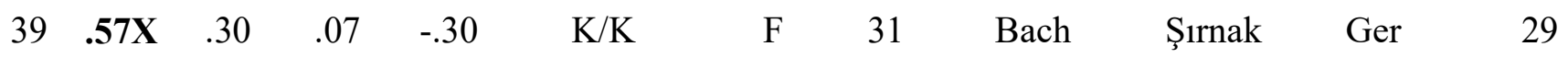

$\begin{array}{llllllllllll}40 & -.13 & .15 & -.01 & \mathbf{5 4 X} & \mathrm{T} / \mathrm{T} & \mathrm{M} & 53 & \text { Prim } & \text { Konya } & \text { Tur } & 40\end{array}$

$\begin{array}{llllllllllll}41 & .07 & -.16 & -.54 & \mathbf{6 1 X} & \mathrm{T}-\mathrm{H} / \mathrm{T} & \mathrm{F} & 65 & \text { Prim } & \text { N/A } & \text { Ger } & 46\end{array}$

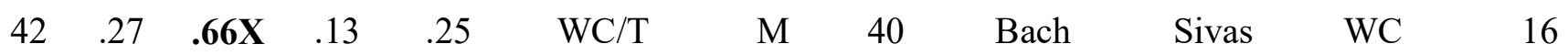




\section{KURDISH-TURKISH DIASPORA IN GERMANY}

Bach N/A Ger

Notes. F1 to F4: Loading on Factors 1 to 4; Loading in bold indicate that the respective sort was used as a defining sort. Identity and language; $\mathrm{T}=$ Turkish, $\mathrm{K}=$ Kurdish, $\mathrm{G}=$ German, $\mathrm{WC}=$ World Citizen, $\mathrm{H}=$ Human; F = Female, $\mathrm{M}=$ Male $;$ Education: Prim = Primary School, $\mathrm{Sec}=$ Secondary School, $\mathrm{HS}=$ High School, Bach = Bachelor; City and Citizen of the Country; N/A =Not Available, Tur $=$ Turkey, Ger $=$ Germany, $\mathrm{WC}=$ World Citizen, $\mathrm{DC}=$ Dual Citizenship, $\mathrm{O}=$ Other. 


\section{KURDISH-TURKISH DIASPORA IN GERMANY}

Table 2

Z-scores of the statements for each factor.

\begin{tabular}{|c|c|c|c|c|c|}
\hline No & Statements & Factors & & & \\
\hline & Domain 1-Problem definitions & F1 & $\mathrm{F} 2$ & $\mathrm{~F} 3$ & F4 \\
\hline 1 & There is no Kurdish Problem; there is a terror problem. & -1.74 & -1.37 & -1.48 & 1.79 \\
\hline 2 & This problem is in facts a democratization problem. & -0.21 & 1.27 & 0.30 & -0.52 \\
\hline 3 & $\begin{array}{l}\text { The status of Kurds in Turkey can be defined in terms of } \\
\text { colonialism. }\end{array}$ & 0.30 & -0.35 & 0.38 & -1.50 \\
\hline 4 & This problem is a class-based problem. & 0.03 & 0.13 & -0.75 & -0.62 \\
\hline 5 & This problem is a problem created by the PKK. & -1.74 & -1.06 & -0.73 & 1.06 \\
\hline 6 & $\begin{array}{l}\text { This problem is an underdevelopment and unemployment } \\
\text { problem. }\end{array}$ & -0.87 & -0.66 & -0.75 & 0.33 \\
\hline 7 & This problem is a Kurdish identity problem. & 0.30 & -0.61 & 1.79 & -0.85 \\
\hline 8 & This problem is Kurds' independence problem. & 0.63 & -0.56 & 2.12 & -0.89 \\
\hline 9 & This problem is a right and freedoms problem. & 0.78 & 1.14 & 1.60 & -0.33 \\
\hline 10 & $\begin{array}{l}\text { There is no Kurdish problem; there are problem of my fellow } \\
\text { Kurdish brothers and sister. }\end{array}$ & -1.59 & -1.75 & -1.10 & 0.04 \\
\hline \multirow[t]{2}{*}{11} & There is no Kurdish problem, there is a Kurdish invasion. & -1.58 & -1.13 & -1.39 & -0.66 \\
\hline & Domain 2-Causes of the problem & & & & \\
\hline 12 & $\begin{array}{l}\text { This problem exists because of the discrimination against } \\
\text { Kurds and the mistreatment of Kurds in the region by state } \\
\text { officials. }\end{array}$ & 0.12 & 0.78 & 0.55 & -0.21 \\
\hline 13 & $\begin{array}{l}\text { This problem exists because of the denial of the Kurds for } \\
\text { many years. }\end{array}$ & 1.24 & 1.66 & 1.51 & -1.06 \\
\hline 14 & This problem stems from the instigation of foreign powers. & -0.21 & -0.95 & -0.19 & 1.10 \\
\hline 15 & This problem stems from the feudal structure in the region. & 0.18 & -0.17 & 0.99 & 0.72 \\
\hline 16 & $\begin{array}{l}\text { The source of the problem is the assimilation policies toward } \\
\text { Kurds and withholding of their cultural rights. }\end{array}$ & 0.87 & 1.29 & 1.51 & -1.00 \\
\hline 17 & $\begin{array}{l}\text { The source of this problem is the nation-state ideology of } \\
\text { Turkey. }\end{array}$ & 0.12 & 1.58 & 0.09 & -0.64 \\
\hline \multirow[t]{2}{*}{18} & The cause of this problem is PKK and terror. & -1.87 & -0.35 & -0.32 & 1.39 \\
\hline & Domain 3-Moral judgments & & & & \\
\hline 19 & Turks and Kurds are fellows & -0.76 & -0.81 & -0.41 & 1.01 \\
\hline 20 & $\begin{array}{l}\text { The media represents this problem to the people in a biased } \\
\text { way. }\end{array}$ & 0.98 & 0.77 & 0.14 & 0.41 \\
\hline 21 & $\begin{array}{l}\text { AKP tries to dominate the region by inciting religious } \\
\text { movements. }\end{array}$ & 0.75 & 0.06 & -0.48 & 0.58 \\
\hline 22 & $\begin{array}{l}\text { You don't have feeling if you don't cry for the terrorist who } \\
\text { dies in the mountains. }\end{array}$ & 0.55 & -0.30 & -0.26 & -0.63 \\
\hline 23 & The PKK is a terrorist organization. & -2.33 & -0.86 & -0.25 & 1.88 \\
\hline 24 & It is unacceptable that HDP embraces PKK militants. & -1.12 & -1.57 & -1.17 & -0.04 \\
\hline 25 & $\begin{array}{l}\text { Kurds and Turks have the same rights; I cannot understand } \\
\text { what Kurds want. }\end{array}$ & -1.14 & -1.20 & -1.77 & 0.66 \\
\hline 26 & The PKK is the actor of the Greater Middle East Project. & 0.60 & -1.21 & -0.73 & 0.17 \\
\hline
\end{tabular}


28 The victims of this problem are the people

29 Kurds are used as pawns by foreign powers.

0.52

\begin{tabular}{rrrr}
0.52 & 0.20 & 0.04 & $\mathbf{- 0 . 7 0}$ \\
.21 & $\mathbf{0 . 3 5}$ & $\mathbf{- 0 . 3 1}$ & 1.11 \\
$\mathbf{0 . 3 6}$ & -1.80 & -1.60 & $\mathbf{1 . 5 8}$ \\
0.05 & -0.39 & $\mathbf{0 . 6 9}$ & $\mathbf{- 1 . 0 2}$ \\
0.20 & 0.59 & -0.68 & -0.52 \\
\hline
\end{tabular}

31 CHP $^{3}$ doesn't work enough for the solution of the problem.

\section{Domain 4-Solutions for the problem}

32 The problem can be solved through deep-rooted

0.33

1.84

0.91

0.31

democratization and implementation of human rights.

33 Turks and Kurds should unite again under the umbrella of Islam.

34 This problem can be solved through economic development and increased job opportunities.

35 An independent Kurdistan should be established.

36 The constitutional recognition of the existence of the Kurdish

$-1.16$

$-0.97-1.62$

$-0.66$ identity is required.

37 The recognition of rights to education and broadcasting in Kurds' own language is required.

38 Local administration should be strengthened.

39 PKK should lay down their weapons.

$\begin{array}{rrrr}0.21 & 0.65 & -0.30 & 1.08 \\ 1.81 & \mathbf{- 0 . 7 9} & 1.80 & \mathbf{- 2 . 2 8} \\ 0.78 & 1.16 & 1.67 & \mathbf{- 1 . 3 1} \\ 1.05 & 1.54 & 1.36 & \mathbf{0 . 0 5}\end{array}$

40 Village guards should be abolished.

$\begin{array}{llll}\mathbf{0 . 8 1} & \mathbf{1 . 3 8} & 0.22 & 0.24\end{array}$

41 Agrarian and land reform should be implemented.

$-1.61$

$1.08 \quad 0.63$

$-0.34$

$-0.80$

42 Kurdish people should be educated.

0.40

$0.17-0.41$

0.82

0.34

$\mathbf{- 1 . 1 2} 0.81$

0.42

1.79

0.31

0.40

$-2.01$

44 The problem can be solved through Turkey's being

0.10

$-0.63$

$-0.69$

0.52

45 The unitary state should not be changed.

46 TSK should fight and end terror through active counter-

$\begin{array}{lll}-1.16 & -1.20 & -1.40\end{array}$

0.70 terrorism policies.

47 The İmralı negotiations should continue.

$-1.47$

$-1.20$

$-1.22$

$-1.14$

$\mathbf{0 . 5 7}$

\section{Domain 5-Barriers to the problem solution}

48 This problem has not been solved because of those who profit from the problem.

49 This problem has not been solved because only harsh security measures have been used.

50 TSK does not want to finish this war.

51 AKP tries to create its own Kurds.

52 This problem has not been solved due to the lack of empathy between the parties.

53 This problem has not been solved because of America's interests in the region.

54 Turkish nationalists are the biggest obstacles to the solution of the problem.

Note. Z-scores in bold are significantly $(p<.05)$ different from each other, indicating

'distinguishing statements.' The specific 54 statements derived from Uluğ and Cohrs's (2016) 
study, with only slight adaptations made to suit the current study. For example, words such as a) BDP (Peace and Democracy Party), b) Oslo, and c) MHP (Nationalist Movement Party) were replaced with a) HDP (People's Democratic Party), b) İmralı, and c) Turkish nationalists, respectively. These minor changes were necessary to meet the current political situation in Turkey (the BDP changed its name, the Oslo negotiations do not continue, and the MHP's situation has changed). 
KURDISH-TURKISH DIASPORA IN GERMANY

Table 3

Correlations Between Factors.

\begin{tabular}{ccccc}
\hline Factor & F1 & F2 & F3 & F4 \\
\hline 1 & - & .59 & .60 & -.54 \\
2 & & - & .58 & -.30 \\
3 & & & - & -.43 \\
4 & & & & - \\
\hline
\end{tabular}




\section{KURDISH-TURKISH DIASPORA IN GERMANY}

Table 4

Comparison of lay people's and Kurdish-Turkish diaspora's viewpoints.

\begin{tabular}{lll}
\hline Study & Viewpoints & Shared by \\
\hline Lay People & Viewpoint-1. Terrorism and Foreign Power Frame & Predominantly Turks \\
Study in & Viewpoint-2. Class, Economy, and Democracy Frame & Predominantly Turks \\
Turkey & Viewpoint-3. Rights, Freedom, and Democracy Frame & Turks/Kurds/Others \\
& Viewpoint-4. Independence Frame & Predominantly Kurds \\
\hline Diaspora Study & Viewpoint-1. Freedom for Öcalan Frame & Predominantly Kurds \\
in Germany & Viewpoint-2. Nation-State Ideology and Democracy & Predominantly Kurds \\
& Frame & \\
& Viewpoint-3. Independence and Identity for Kurds & Kurds/Turks \\
& Frame & \\
& Viewpoint-4. Terrorism and Foreign Power Frame & Predominantly Turks \\
\hline
\end{tabular}




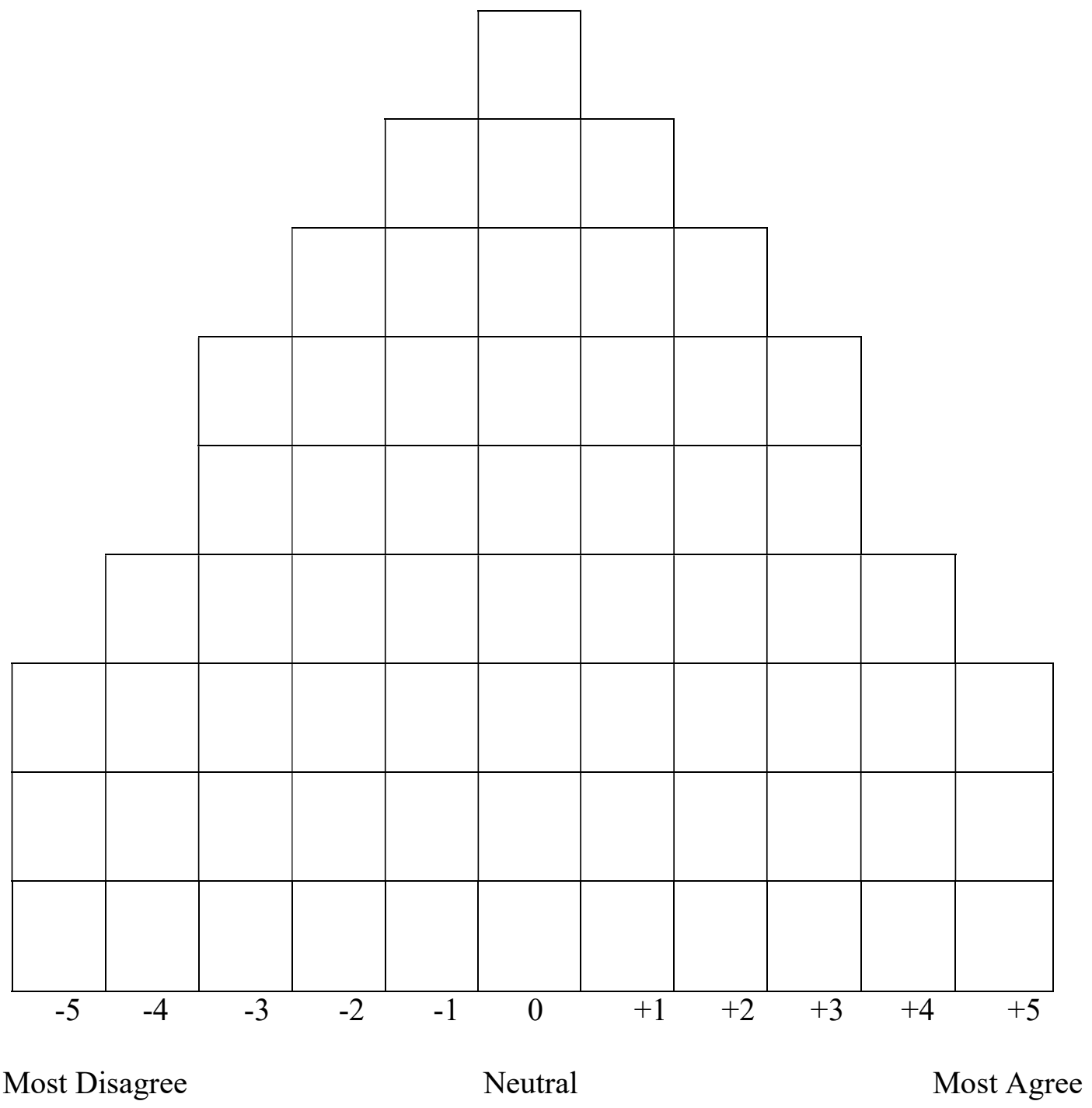

Figure 1. The fixed quasi-normal distribution. 